\title{
Pola tematyczne współczesnego specjalistycznego słownictwa morskiego
}

Thematic fields of the contemporary Polish specialized maritime vocabulary

\section{Halina GAJEWSKA}

Uniwersytet Szczeciński, Akademia Morska w Szczecinie/ University of Szczecin, Maritime University of Szczecin

E-mail: gajewskahala@gmail.com,

\begin{abstract}
The objective of the following paper is to present and analyze the thematic fields of specialized nautical vocabulary that constitute the macrostructure of the monolingual maritime Polish dictionary of which I am the author. The thematic fields comprise the specialized maritime lexis which depicts the most important fragments of the contemporary reality of seafarers. The research material has been excerpted from the sources published after 1989.
\end{abstract}

Keywords: Polish specialized maritime vocabulary, maritime terms, thematic fields, monolingual dictionary, LSP

\section{Wstęp}

Celem niniejszego artykułu jest przedstawienie i omówienie 30 pól tematycznych składających się na makrostrukturę słownika morskiego mojego autorstwa. Morski język specjalistyczny jest narzędziem komunikacji ludzi morza. Są to marynarze, pracownicy portu oraz studenci, nauczyciele i profesorowie szkół i akademii morskich. Tematy, wokół których skupia się ta specjalistyczna komunikacja dotyczą zagadnień zawodowych, mających na celu efektywną i fortunną wymianę informacji pomiędzy jej uczestnikami. Nadawca i odbiorca posiadają już pewną wiedzę specjalistyczną, a język zawodowy służy im do dalszego poszerzania swoich umiejętności i zdobywania informacji o obiektach specyficznych dla rzeczywistości morskiej. Rola języka specjalistycznego wykracza poza sferę komunikacji, gdyż jest on wskaźnikiem rozwoju i postępu cywilizacyjnego danej społeczności (por. S. Grucza 2013: 6-9, J. Lukszyn 2005: 40). W odróżnieniu od polszczyzny ogólnej, zrozumiałej dla całości polskiego społeczeństwa, specjalistyczny język morski posługuje się zasobem leksyki i terminologii odnoszącym się do tradycji zawodu marynarza, przez co może być niejasny dla osób spoza tej grupy zawodowej (zob. S. Grabias 1997: 133-135).

\section{Metodologia badań}

W prezentowanym artykule realia morskie, od najprostszych po wysoce zaawansowane technologicznie, ujęte zostały w pola tematyczne, konstytuujące makrostrukturę 
monolingwalnego słownika morskiego. Podstawę źródłową utworzonych pól stanowią specjalistyczne czasopisma branżowe o tematyce morskiej, podręczniki akademickie omawiające zagadnienia ściśle powiązane z konkretnymi dziedzinami nauki związanymi z pracą na morzu oraz kształceniem w zawodzie marynarza, słowniki ogólne polszczyzny, monolingwalne i bilingwalne (angielsko-polskie i polsko-angielskie) słowniki dla marynarzy oraz strony internetowe poruszające aktualne zagadnienia morskie.

Do czterech magazynów morskich, z których pochodzi materiał badawczy, należą miesięczniki o następujących tytułach: „Bandera” z roku 2011 oraz dwa miesięczniki z roku 2008 - „Żagle” i „Nasze Morze”. Ich uzupełnienie stanowi dwutygodnik „Namiary na Morze i Handel", pochodzący z roku 2008. Powyższy wybór został podyktowany bogactwem leksyki specjalistycznej użytej w kontekście i obejmującej swym zakresem cztery różne dziedziny społeczno-gospodarcze związane z morzem. Do przewodnich tematów wspomnianych czasopism należą odpowiednio: marynarka wojenna, żeglarstwo, rybołówstwo i transport morski.

Kolejną część bazy materiałowej stanowią podręczniki studentów nawigacji oraz poradniki dla marynarzy i żeglarzy. Z powodu dużej ilości tych publikacji (około 60) wymienię tylko kilka najistotniejszych: Bezpieczeństwo Nawigacji I. Jagniszczaka i E. Łusznikowa z 2010, Vademecum Nawigatora Franciszka Wróbla z 2009, Plan ładunkowy statku handlowego B. Łączyńskiego i A. Starosty z 2006, Przewozy Morskie. Część pierwsza z 2007 B. Łączyńskiego, Podręcznik Międzynarodowego Prawa Drogi Morskiej W. Rymarza z 1998, Podstawy manewrowania statkiem morskim. Kurs manewrowania na symulatorze A. Nowickiego i J. Kabacińskiego z 2008 oraz Podręcznik żeglarza i sternika jachtowego F. Habera z 2009. Zawierają one interesujące mnie profesjonalne słownictwo i pozwalają poszerzyć zakres omawianej leksyki o terminy pochodzące ze specjalistycznych publikacji.

Obok wymienionych czasopism morskich i podręczników na źródło materiału badawczego składają się słowniki specjalistyczne rejestrujące leksykę morską. Dwa najważniejsze z nich, oba opracowane w układzie alfabetycznym, to jednojęzyczny Mały słownik morski L. Furmagi i J. Wójcickiego z roku 1993 oraz Słownik okrętowy, angielsko-polski i polsko-angielski Jana Babicza z 2004 roku. Mały słownik morski, jak zaznaczają jego autorzy w jednostronicowym wstępie, jest przeznaczony dla żeglarzy, modelarzy i czytelników literatury morskiej. Jest to słownik encyklopedyczny, w którym obok haseł objaśniających różnorodne urządzenia i części statków, zawarte są informacje biograficzne przybliżające sylwetki ludzi morza oraz nazwy własne, jak np. Ocean Atlantycki. W sumie 1920 haseł (nie licząc nazw własnych i not biograficznych) zostało zamieszczonych na 266 stronach. Słownik ten posiada ubogą mikrostrukturę, ograniczającą się jedynie do definicji. Hasła nie posiadają kwalifikatorów, informacji etymologicznej ani gramatycznej. Autorzy tej pracy leksykograficznej Furmaga i Wójcicki - opierają się na własnej praktyce morskiej, umożliwiającej im zdefiniowanie określeń używanych w komunikacji marynarzy i żeglarzy morskich, jednak nie można się zgodzić z opinią wyrażoną we wstępie, że jest to słownik terminów, ponieważ występuje w nim również słownictwo, które nie spełnia kryteriów definicji terminu. Drugi z wymienionych słowników, autorstwa J. Babicza, składa się z 
czterech rozdziałów zamieszczonych na 574 stronach. Część pierwsza, objętościowo największa, to słownik angielsko-polski obejmujący 393 strony. Rozdział drugi składa się z czterdziestu planszy tematycznych z angielsko-polskimi ekwiwalentami, są to zdjęcia i szkice ilustrujące części statku i jego urządzenia, np. ładownię masowca, osprzęt cumowniczy. Kolejny, trzeci rozdział stanowi słownik polsko-angielski zawarty na 97 stronach. Ostatni element składowy słownika to zestawienie 180 angielskich akronimów i skrótów z uwzględnieniem ich pełnej nazwy po angielsku, bez przywoływania polskich ekwiwalentów.

Poniżej omówiono dwa sposoby objaśniania haseł w słowniku J. Babicza, z których pierwszy występuje zarówno w części angielsko-polskiej, jak i polsko-angielskiej, a drugi tylko w części angielsko-polskiej:

1) definicja synonimiczna, np.: ,jig - łoże montażowe” (2004: 225), „osuszanie - drainage" (2004: 514);

2) definicja realnoznaczeniowa, np.: ,offshore loading systems - systemy używane do ładowania surowej ropy $\mathrm{z}$ instalacji produkcyjnych na tankowce wahadłowe. Offloading systems for floating production units (FPU), floating production/ storage vessels (FPSOs) and shuttle tankers..." (2004: 270).

Ograniczenie definicji do podania odpowiednika w języku docelowym (przypadek 1) przybliża to dzieło leksykograficzne do glosariusza terminologicznego, z kolei dokładne, szczegółowe opisy merytoryczne po polsku i angielsku (przypadek 2) wskazują na pozycję encyklopedyczną. Za M. Klawe (2014: 121) nazywam słownik łączący oba typy przedstawionych opisów leksykograficznych, w którym realnoznaczeniowe i rozbudowane definicje dotyczą tylko części, zazwyczaj bardziej wyspecjalizowanych, terminów słownikiem hybrydalnym.

Analizowane rozbieżności w mikrostrukturze artykułu hasłowego nie pozostały bez wpływu na makrostrukturę prezentowanego dzieła leksykograficznego. Prawdopodobnie brak polskich ekwiwalentów dla części angielskich terminów przyczynił się do większej objętości rozdziału pierwszego, angielsko-polskiego (8000 haseł) w porównaniu z częścią trzecią, polsko-angielską (4000 haseł). Pomimo zaobserwowanych dysproporcji, uważam, że analizowany słownik jest cennym źródłem morskiej leksyki i terminologii, stworzonym dla wąskiej grupy osób zainteresowanych specjalistycznym słownictwem morskim, budową statków i przemysłem morskim.

$\mathrm{Z}$ powodu braku innych współczesnych słowników encyklopedycznych uzupełnienie zasobu leksykalnego stanowi Ilustrowany angielsko-polski słownik marynarza z 2007 roku, zawierający, na ponad sześciuset stronach, około 7000 haseł w układzie rzeczowym oraz wydany w 2011 roku angielsko-polski słownik komend morskich pt. Standardowe zwroty porozumiewania się na morzu E. Plucińskiej i J. Kłosińskiego. Pierwszy z wymienionych słowników, autorstwa J. Puchalskiego, składa się z dwunastu pól tematycznych, np. Teoria okrętu, z których każde obejmuje od dziesięciu do dwudziestu podpól, co w połączeniu z licznymi szkicami i załączoną listą skrótów i indeksem jednostek leksykalnych stanowi imponujący rezultat pracy leksykograficznej. Z kolei wspomniany słownik komend to zebrane w układzie tematycznym kategorie odnoszące się do najważniejszych zagadnień komunikacji morskiej, jak np. Łączność w niebezpieczeństwie. Przedmiotem mojego zainteresowania we wszystkich 
wymienionych słownikach są tylko jednostki leksykalne przynależne do czterech głównych grup tematycznych, mianowicie: żeglarstwa, marynarki wojennej oraz transportu morskiego i rybołówstwa.

Do przedostatniego źródła materiałowego należą słowniki polszczyzny ogólnej S. Dubisza i W. Doroszewskiego, notujące popularne terminy i profesjonalizmy morskie oznaczone kwalifikatorami profesjonalno-naukowymi: mors., mors. żegl., mors. tech., zaw. mors., ryb. oraz socjolektalno-środowiskowymi: środ. mors., środ. mors. żegl. i środ. mar. Kwalifikatory te określają przynależność jednostek leksykalnych do specjalnego słownictwa morskiego z uwzględnieniem terminologii. Oznaczona wymienionymi kwalifikatorami leksyka morska zawiera więc zarówno pozbawione ekspresji terminy i leksemy zawodowe, jak i nacechowane emocjonalnie wyrazy środowiskowe.

Ostatnie źródło morskiego słownictwa specjalistycznego stanowią strony internetowe poruszające zagadnienia morskie. Najpopularniejsze to: Portal Morski, Polski Rejestr Statków, Nasz Battyk i Gospodarka Morska. Podobnie jak w wyżej wymienionych bazach materiałowych, w przypadku wspomnianych stron internetowych interesuje mnie leksyka specjalistyczna związana z transportem morskim, marynarką wojenną, żeglarstwem i rybołówstwem.

Klasyfikacja zebranego materiału leksykalnego w określonych grupach według kryterium onomazjologicznego stanowi cel badań i punkt wyjścia do analizy semantyczno-formalnej.

\section{Porządek tematyczny}

Słownik został zredagowany w układzie rzeczowym, wykorzystującym do usystematyzowania słownictwa teorię pól językowych ${ }^{1}$, która jest stosowana w językoznawstwie do analizy i porządkowania leksyki jako podstawowego obok gramatyki systemu języka. Badanie słownictwa w oparciu o teorię pola językowego ${ }^{2}$ jest, jak pisze W. Miodunka, przeciwstawieniem się ,,analizie znaczeniowej pojedynczych, izolowanych wyrazów” (1980: 16) i nawołaniem ,do opisu znaczenia całych grup wyrazowych" (1980: 16). Leksemy w obrębie jednego pola mają powiązanie znaczeniowe, wzajemnie warunkując swoje znaczenie, dopełniają i wzbogacają całościowy obraz grupy tematycznej.

W centrum moich zainteresowań są terminy i profesjonalizmy morskie oraz żeglarskie, z których zostały utworzone pola ${ }^{3}$ tematyczne. Zarówno pojęcie ,ppole tematyczne”, jak i ,,pole leksykalno-semantyczne” (zob. R. Tokarski 1984a: 86) oraz inne

\footnotetext{
${ }^{1} \mathrm{Na}$ gruncie polskiego językoznawstwa jako pierwszy zajął się zagadnieniem pól językowych W. Miodunka (zob. W. Miodunka 1980).

${ }^{2}$ Prekursorami tej teorii są G. Ipsen, J. Trier, A. Jolles, W. Porzig, L. Weisgerber (zob. W. Miodunka 1980: 18).

${ }^{3}$ Pierwszy terminu ,pole” użył w 1874 roku E. Tegner w pracy Språk och nationalitet w odniesieniu do podziału odbijającego się w języku ludzkiej świadomości. Twórcą natomiast terminu ,pole znaczeniowe” jest G. Ipsen (zob. W. Miodunka 1980: 18-22).
} 
terminy stosowane w literaturze przedmiotu (jak pole semantyczne, znaczeniowe, leksykalne, wyrazowe, pojęciowe) zostały szczegółowo omówione między innymi przez W. Miodunkę (1980), Z. Cygal-Krupę (1990) i R. Tokarskiego (1984b). W. Miodunka poprzez pole znaczeniowe, semantyczne rozumie ,zbiór dystrybucji jednego wyrazu, w którym posiada on swoiste znaczenie" (1980: 54). Z kolei termin pole wyrazowe, leksykalne uczony określa jako ,zbiór wyrazów zawierających w swych znaczeniach elementy (semy) wspólne i dzięki temu wchodzących w różnego rodzaju relacje" (1980: 54). W. Miodunka zauważa (1980: 54), że klasyczni twórcy ${ }^{4}$ J. Trier i W. Porzig, badający relacje semantyczne w oparciu o idee Saussure'a ${ }^{5}$, używali tych terminów często wymiennie. Z. Cygal-Krupa stosuje określenie pole tematyczne, które definiuje jako ,zbiór wyrazów możliwych funkcjonalnie w konkretnej sytuacji tematycznej” (1990: 26). Kolejny badacz, R. Tokarski, opisuje pole leksykalno-semantyczne jako ,grupę wyrazów powiązanych wspólnym znaczeniem, między którymi istnieją relacje znaczeniowe, dające w konsekwencji system zwarty i hierarchiczny" (1984a: 86). Tematyką pola semantycznego zajmowali się również D. Buttler, A. Markowski i J. Wierzchowski. Pola znaczeniowe i leksykalne służą do interpretacji znaczeniowej i porządkowania zasobów wyrazów polszczyzny ogólnej, z kolei grupy tematyczne ujmują leksykę specjalną używaną przez określoną grupę społeczną lub zawodową.

W niniejszym artykule stosuję pojęcie ,,pole tematyczne”, gdyż badana leksyka i terminologia powiązane są nadrzędnym tematem, jaki stanowi morze, i przynależą do słownictwa specjalistycznego. W języku zawodowym ludzi morza, obok naukowych, oficjalnych terminów współistnieją nieoficjalne profesjonalizmy, stanowiące podstawę skutecznej komunikacji między członkami załogi na statku, czy pracownikami w porcie. Sytuacje komunikacyjne mające miejsce na pokładzie jednostki pływającej wymagają od nadawcy i odbiorcy nie tylko znajomości terminów i profesjonalizmów, ale też określonej wiedzy i kompetencji.

\section{Analiza semantyczno-formalna pól tematycznych}

W omawianym materiale badawczym nazwy poszczególnych pól tematycznych czy centrów zainteresowań stanowią przewodnią tematykę każdego pola znaczeniowego i określają stopień rozpiętości znaczeniowej leksemów zawartych w danym polu. W zależności od stopnia semantycznego powiązania leksemu z nazwą pola, dany leksem stanowi centrum lub peryferie określonej grupy. Nazwy centrów zainteresowań zostały zakwalifikowane w 3 grupach (zob. Z. Cygal-Krupa 1990: 87): nazwy jednopojęciowe, np.: 1. Historyczne jednostki pływające, 2.2. Łodzie, 2.3. Żaglowce, 2.4. Jachty, 11. Kotwice; nazwy dwupojęciowe, jak np.: 3. Wyposażenie i urządzenia na

\footnotetext{
${ }^{4}$ Teoria pola językowego rozwinęła się w latach 20 XX w. w Niemczech, a za jej twórców, oprócz J. Triera i W. Porziga, uważa się G. Ipsena, A. Jollesa i L. Weisgerbera (zob. W. Miodunka 1980: 18).

${ }^{5}$ Według F. de Saussure'a wszystkie znaki językowe są ze sobą ściśle powiązane i dlatego wyrazów nie powinno się analizować w izolacji, tylko na tle większych grup (zob. W. Miodunka 1980: 11).
} 
statku, 29. Rybołówstwo i sprzęt połowowy, 7. Omasztowanie i drzewce oraz nazwy trójpojęciowe, określające pola typu: 2.1. Jednostki pływające, typy statków i ich nazwy grupowe, 9. Węzły, sploty, wiązania, 18. Stocznia, remont i konserwacja statku, 20. Zespoły ludzkie, oddziały wojskowe, organizacje, 23.3. Pływy, prądy, fale. Nadrzędnym celem w budowaniu kręgów tematycznych analizowanego słownika było zebranie materiału leksykalnego szeroko powiązanego ze specjalistyczną tematyką morską $\mathrm{z}$ ukierunkowaniem na nawigację. $Z$ tego też powodu, jednym z materiałów źródłowych badanego języka specjalistycznego były podręczniki studentów nawigacji, w oparciu o które powstały takie określenia centrów zainteresowań, jak: 21. Stateczność i 22.2. Nawigacja w lodach i 27. Przewóz i przeładunek towaru. $Z$ kolei pole tematyczne 3.4. Wyposażenie siłowni zostało uwzględnione $\mathrm{w}$ opracowanym słowniku w okrojonym zakresie, gdyż zawarto w nim jednostki leksykalne, które nie wykraczają poza wiedzę nawigatora na temat siłowni okrętowych. Pozostałe nazwy centrów tematycznych są wypadkową zakresów tematycznych pozostałych wyekscerpowanych jednostek leksykalnych i łączą wspólne elementy znaczeniowe zawartych w nich leksemów.

Tematyczność jest istotnym atrybutem zawodowej leksyki. J. Lukszyn, określając cechy słownictwa specjalistycznego, będącego ,zbiorem jednostek leksykalnych właściwych dla komunikacji zawodowej” (2005: 104), wymienia jego podzielność tematyczną, definiując ją jako „odzwierciedlenie różnych aspektów analizy obiektów pracy zawodowej” (2005: 104). Pola tematyczne, stanowiące podstawę omawianego słownika morskiego, z jednej strony mają za zadanie pokazanie szerokiego spektrum zawodowych tematów wchodzących w obręb profesjonalnego słownictwa morskiego, $z$ drugiej strony prezentują jego złożoność i wysoki poziom specjalizacji. Rzeczywistość morska w badanym słowniku została zinterpretowana i ujęta w 30 pól tematycznych, zawierających ponad 3920 jednostek leksykalnych, powiązanych znaczeniowo i zgrupowanych wokół przewodniego centrum tematycznego, determinującego dobór wyrazów w poszczególnych polach. Ze względu na dużą ilość materiału leksykalnego, jako przykłady została przedstawiona tylko jego reprezentatywna część. Klasyfikacja zebranego zasobu słownego i terminologicznego w określonych grupach tematycznych według kryterium onomazjologicznego stanowi punkt wyjścia do analizy i interpretacji znaczeń zebranych jednostek leksykalnych. Każde pole nawiązuje do istotnych zagadnień zawodu marynarza, począwszy od typów dawnych statków, po statki współczesne, ich wyposażenie i konstrukcję oraz podział przestrzenny, po bardziej szczegółowe części statków, jachtów i okrętów jak omasztowanie, żagle, olinowanie, łańcuchy, kotwice etc. Następne pola obejmują zagadnienia z zakresu manewrowania, bezpieczeństwa i komunikacji, kończąc na profesjach powiązanych z morzem i dziedzinach wiedzy morskiej jak stateczność, nawigacja i astronawigacja oraz geografia morza i meteorologia etc. Wszystkie omawiane pola tematyczne mają charakter otwarty, można je wzbogacić o kolejne jednostki leksykalne, stąd też ich granice nie są stałe.

Jednostki leksykalne reprezentujące pierwsze dwadzieścia dziewięć kategorii tematycznych ograniczają się do rzeczowników. Nazwy wszelkiego rodzaju aktywno- 
ści określane przez czasowniki zostały zawarte w ostatnim polu 30. Czynności i procesy. Całość zebranego materiału leksykalnego podzieliłam na następujące pola tematyczne:

1. Historyczne jednostki pływające, np. : awizo, bat, birema, bryg, brygantyna, dtubanka, drakkar, dromona, dubas, dungija, feluka, fleuta, galeas, galeon, galera, holk, statek okragty, żaglowiec jednorzędowy.

2. Współczesne jednostki pływające, nazwy grupowe statków i okrętów.

2.1. Jednostki pływające, typy statków i ich nazwy grupowe, np.: apartamentowiec, asfalciarka, asfaltowiec, bagier, bagrownica, bananowiec, barka, barkas, barkowiec, batyskaf, baza przetwórnia, bulk carrier, statek dźwignicowy, pociag holowniczy, statek ograniczony swym zanurzeniem.

2.2. Łodzie, np.: bąk, dezeta, drebel, gig, hojer, jola, kanu, klinkierówka, kuter, ponton, skif, szalupa, umiak, welbot, tódź hybrydowa, zrzutowa tódź ratunkowa.

2.3. Żaglowce, np. : bark, barkentyna, bryg, fregata, jol, kecz, ket, lugier, pelnorejowiec, rejowiec, szkuner, żaglowiec, petnorejowiec.

2.4. Jachty, np.: bojer, monotyp, slup, słonka, szpicgat, sunfish, ślizg, tempest, trimaran, katamaran, ślizg lodowy, jacht mieczowy.

2.5. Okręty wojenne, ich właściwości, nazwy grupowe okrętów, np.: fregata, kanonierka, brygada, brandwachta, desantowiec, drednot, dywizja, eskortowiec, kuter rakietowy, autonomiczność okrętu, baza plywająca, bazowe środki pływajace, pancernik obrony wybrzeża.

3. Wyposażenie i urządzenia na statku.

3.1. Wyposażenie mostka, urządzenia nawigacyjne i przyrządy pomiarowe, np.: barograf, log, diafon, kompas, mareograf, chronometr, migacz, aksjometr, reflektor sygnałowy, chronometr morski, cyrkiel nawigacyjny, zawieszenie kardana.

3.2. Wyposażenie pokładowe, np.: bęben, wciagarka, blok, bramownica, braszpil, sztormtrap, fajka, handszpak, kabestan, knaga, automat cumowniczy, policzek bloku, winda kotwiczna, drabinka pilotowa, składana pokrywa lukowa, hamulec łańcucha, kotwicznego, rampa rufowa obrotowa, orzech bębna windy kotwicznej.

3.3. Wyposażenie pomieszczeń dla załogi, np.: bakista, baryłka, hamak, koja, nietoperz, klimatyzacja, wentylacja, koja wisząca, krata stołowa, rozgłośnia statkowa.

3.4. Wyposażenie siłowni, np.: akcelerometr, armatura, dmuchawa, drenaż, ė̇ektor, klaryfikator, amortyzator kołysania, instalacja balastowa, ciśnienie dopuszczalne, instalacja gazu obojętnego, wyrzutnik popiołu i śmieci, centralny uktad zalewania pomp;

4. Dawne i współczesne wyposażenie i urządzenia militarne na okręcie wojennym, np.: artyleria, balista, bombarda, chrapy, falkonet, peryskop, torpeda, bomba głebinowa, barbeta burtowa, broń podwodna, działo kalibru głównego, miotacz pocisków gtębinowych, protektor pola minowego.

5. Konstrukcja jednostki pływającej, np.: achterdek, aflaston, bakbort, bakburta, batoks, bims, dejwud, dennik, dziobnica, filar, gródź, czop, głowica, sterownica, rumpel, szturwat.

6. Budowa statku - podział przestrzenny, np.: achterluk, bak, balast, bond, bunkier, burtówka, cokót, dek, dulklapa, dziobówka, fordek, forpik, greting, kabelgat;

7. Omasztowanie i drzewce np.: bramstenga, bukszpir, bukszpryt, dziobak, delfiniak, tabędziak, rozpórka, drzewce, dyby, flagsztok.

8. Ożaglowanie i osprzęt żeglarski np.: balonfok, apsel, bant, banta, bezan, blind, bomkliwer, bramsel, fok, bryt, genaker, grot, guari, kliwer, latacz, lik, luwers, pik, petzacz. 
9. Węzły, sploty, wiązania, np.: gałka, grumot, klajdunek, lora, motowiazanie, splot, stoper, oko, wyblinka, swajka, szplajs.

10. Olinowanie, cumy, łańcuchy, np.: brest, buchta, chomatko, ciag, cuma, dirka, faleń, falrep, fat, fit, gaja, hol, jufer, kotkownica, kotek.

11. Kotwice, np.: drapacz, kabel, kot, krętlik, krzyzulec, pazur, przęsło, trent, werp.

12. Manewrowanie, np.: chwiejba, oko, dobijanie, dryf, ewolucja, hals, topot, manewr.

13. Cumowanie, np.: bosak, cumowanie, cumownica, dalba, knecht, odbijacz, pachot, pacholek, poler.

14. Bezpieczeństwo załogi i statku, np.: asysta, kapok, ponton, sptynięcie, sztormiak, sztormówka, sztrandowanie, wyciek, zalewanie, ześlizg.

15. Komunikacja (alarmy, sygnalizacja, oznakowanie statku, międzynarodowy kod sygnałowy), np.: alarm, bandera, dzwon, dźwięk, flaga, gala, język, klang, marka.

16. Komendy, sygnały, zawołania, np.: ,, wiosła”, szklanki, ,, bosak”, ,, basta”, ,, ahoj!”.

17. Światła i znaki nawigacyjne, np.: baken, boja, nabieżnik, niedziałajacy, pława, plawka, plywak, stawa, tyka, wiecha.

18. Stocznia, remont i konserwacja statku, np.: awaria, baszta, dok, heling, kadtubownia, karenaż, klamra, kotyska, konserwacja, korozja, legar.

19. Ludzie morza (załoga, pracownicy portu, funkcje, stanowiska oraz stopnie wojskowe i żeglarskie), np.: admirat, armator, blinda, bosman, brygadzista, chwytakowy, cleaner, cumownik, dejman, desantowiec, dewiator, dźwignicowy, galernik, hakowy, klark.

20. Zespoły ludzkie, oddziały wojskowe, organizacje, np.: admiralicja, ganek, gang, konferencja, maszoperia, nadwachta, podwachta, wachta, załoga, raczka.

21. Stateczność, np.: inercja, metacentrum, naprężenie, obciążenie, pływalność, podoblenie, przechyt, przegtębienie, trym, wodnica, wypór, wznios, zanurzenie.

22. Nawigacja, np.: trasa, trawers, rejs, rumb, podwietrzna, nawietrzna, eskorta, hals, izobata, kabel, kierunek, kilwater, kurs, odstęp, peleng, nawietrzność, namiar.

22.1. Mapy i wydawnictwa nawigacyjne, np.: agona, korekta, locja, plan, plotingi, sążeń, skala, stopa.

22.2. Nawigacja w lodach, np.: płona, płoń, przerwa, growler, pak, przylepa, rynna, śryż, kasza, nawarstwianie, oblodzenie, kra, lepa, lodowiec, toros, zawiesina.

22.3. Astronawigacja, np.: azymut, kulminacja, wysokość gwiazdy, zmrok cywilny, widoczny wschód słońca.

23. Geografia i meteorologia.

23.1. Geografia morza, np.: abisal, abrazja, antycyklon, archipelag, atol, cieśnina, cyklon, cypel, depresja, fiord, gtębia, izohalina, laguna, luminescencja, tawica, mielizna, mierzeja.

23.2. Wiatr, np.: bora, bryza, cyklon, fleuta, gibli, huragan, mistral, monsun, orkan, pasat, szkwat, sztorm, sztil, tajfun, tornado, wimpel.

23.3. Pływy, prądy, fale, np.: dryf, dryft, dziad, dziadek, grzebień, grzywacz, kipiel, odplyw, plyw, przyplyw, rozkolys, tsunami.

24. Eksploracja morza, np.: akwalung, batometr, batysfera, pepowina, ksantometr, salinometr, wiatromierz, skafander, świder, strimer, trenczer.

25. Działy wiedzy o morzu, np.: astronawigacja, automatyka, dewiacja, hydrologia, locja, manewrowanie, nautologia, nautyka, oceanografia, nawigacja, oceanologia.

26. Port, akweny, np.: akwatorium, akwen, awanport, baba, kafar, basen, baza, terminal, bosmanat, dejmanka, kanat, kapitanat, kaszyca, keja.

27. Przewóz i przeładunek towaru, np.: baryłka, bieżnik, bunkier, drewno, drobnica, dyspasza, dźwig, elewator, fracht, hiw, inertowanie, kabotaż. 
28. Dokumenty i prawo morskie, np.: abandon, angaria, arbitraż, bodmeria, czarter, czarterpartia, embargo, konosament, musterrola, pryz.

29. Rybołówstwo i sprzęt połowowy, np.: błystka, brodnia, cedzak, grzęza, harpun, haczyk, hol, igliczka, iglica, kacerz, łowisko, manca, net.

30. Czynności i procesy, np.: bagrować, brasować, buchtować, hisować, likować, żeglować.

Na podstawie zebranego materiału można stwierdzić, że poszczególne grupy tematyczne różnią się między sobą ilością zgromadzonych jednostek leksykalnych i strukturą semantyczną. Struktura ta odzwierciedlona jest w znaczeniowych relacjach nadrzędności/podrzędności między leksemami, które funkcjonują wówczas jako hiperonimy i hiponimy ${ }^{6}$ oraz w relacji semantycznej współrzędności, gdy jednostki leksykalne współistnieją jako kohiponimy. Najbogatsze i najobszerniej rozbudowane pole 2. Współczesne jednostki pływające, nazwy grupowe statków i okrętów zawiera w sumie 582 jednostki leksykalne i posiada najwięcej podpól, w tym wypadku pięć, $\mathrm{z}$ których pierwsza grupa ma najszerszy zakres znaczeniowy, obejmując wszelkie jednostki, głównie statki, a każde kolejne podpole odnosi się do innego rodzaju jednostek pływających w następującej ilości: 2.1 jednostki pływające, statki 369, 2.2 łodzie 64, 2.3 żaglowce $25,2.4$ jachty 22 oraz 2.5 okręty wojenne 105 . Następne pod względem liczebności leksemów są grupy tematyczne: 3. Wyposażenie i urządzenia na statku zawierająca cztery podpola, składające się w sumie z 370 leksemów, 5. Konstrukcja jednostki pływającej z czterema podpolami w ilości 334 leksemów i 27. Przewóz i przeładunek towaru z 245 jednostkami. Najmniej liczną grupą leksykalną stanowi podpole 3.3 Wyposażenie pomieszczeń z 14 jednostkami leksykalnymi, 16. Komendy, sygnały, zawołania z 19 i pole 13. Cumowanie z 20 jednostkami leksykalnymi.

O przyporządkowaniu leksemu do określonego pola decydowały jego prymarne cechy semantyczne. Problem metodologiczny stanowiły leksemy, których zakres znaczeniowy obejmował kilka pól lub takie, których znaczenie nie odpowiadało żadnemu centrum tematycznemu. Przykładem jednostek terminologicznych o szerokim zakresie znaczeniowym są łódź ratownicza, łódź ratunkowa, zrzutowa łódź ratunkowa $i$ szybka łódź ratownicza. Semantycznie, wymienione połączenia terminologiczne obejmują pola 2.2 Łodzie i 14. Bezpieczeństwo załogi i statku, należąc do jednostek pływających określanych jako łodzie, ostatecznie znalazły swoje miejsce w polu 2.2, gdzie sytuują się wokół centrum tematycznego jako jeden z wielu typów łodzi, podczas gdy ich funkcja ratownicza zyskała status sekundarnej cechy semantycznej. Z kolei synonimiczne jednostki wodolot, wodnosamolot, hydroplan, stanowiące nazwy samolotów zdolnych do startowania i lądowania na wodzie, nie mieszczą się w centrum tematycznym żadnego z podpól pola drugiego obejmującego statki, łodzie, żaglowce, jachty, okręty wojenne. Ten ciekawy łańcuch synonimiczny, pochodzący z

${ }^{6}$ J. Lukszyn definiuje hiponim i hiperonim w następujący sposób: „Jeżeli jedno pojęcie obejmuje wszystkie cechy drugiego i ponadto jedną cechę dodatkową, to takie pojęcie jest pojęciem podrzędnym (hiponimem) w stosunku do drugiego, które jest pojęciem nadrzędnym (hiperonimem) (zob. 2005: 85). 
Małego Słownika Morskiego, jednego z podstawowych źródeł materiałowych powstałej pracy, zaburzył jasny i precyzyjny podział jednostek pływających według nazw wspomnianych podpól. W makrostrukturze omawianego słownika morskiego zabrakło miejsca nie tylko na leksem wodnosamolot i jego synonimy, ale również na rzeczownik wodnoszybowiec. Ostatecznie, aby właściwie zakwalifikować problematyczne terminy, centrum pola tematycznego 2.1 zostało poszerzone o jednostki pływające, gdzie statki stanowią jego punkt centralny, nie wykluczając jednak leksemów wodnosamolot i wodnoszybowiec, które odnalazły swoje miejsce na obrzeżach tego kręgu tematycznego.

Na uwagę zasługuje fakt, że omawiane jednostki leksykalne w zależności od kontekstu, w którym występują, otrzymują status terminu, profesjonalizmu, połączenia terminologicznego lub funkcjonują jako wyrazy, połączenia wyrazowe. Granica między warstwą ogólną i specjalistyczną słownictwa polskiego nie jest ostra, a decydującą rolę w określeniu jednostki leksykalnej mianem wyrazu lub terminu zależy nie tylko od tego, czy jest ona nośnikiem wiedzy specjalistycznej czy ogólnej, ale również od kontekstu, w którym występuje. Wyrazy funkcjonują w polszczyźnie standardowej, a terminy i profesjonalizny przynależą do języka specjalistycznego z tym jednak rozróżnieniem, że terminy są naukowe i oficjalne, a profesjonalizmy potoczne, mniej oficjalne. B. Ligara zauważa, że dychotomię metodologiczną między językiem ogólnym i specjalistycznym, ,wyznaczają wymogi terminologii (terminoznawstwa) jako dyscypliny naukowej, od których językoznawstwo nie może abstrahować" (B. Ligara 2017: 30).

Zawodowa (specjalistyczna) leksyka morska stanowi podstawę zasobu leksykalnego morskiego języka specjalistycznego. Występują tu terminy, które, za S. Gajdą, definiuję jako ,jednostki leksykalne spełniające funkcję znaku profesjonalnego pojęcia" (1990: 38) oraz leksyka profesjonalna (profesjonalizmy), do której przynależą wyrazy środowiskowe (codzienne, obiegowe) i zawodowe. W sprecyzowaniu, czy dana jednostka leksykalna jest terminem, należy, według S. Gajdy, wziąć pod uwagę pięć cech: profesjonalną i ograniczoną sferę użycia, definicyjność (termin występuje jako znak wprowadzonej definicji), systemowość (wyrażone pojęcie fachowe stanowi element szerszego systemu pojęć, terminologii), jedno-jednoznaczną odpowiedniość między pojęciem i terminem (brak polisemii i synonimii) oraz nieekspresywność (1990: 39).

Istotną cechą różniącą poszczególne jednostki leksykalne zawarte w omawianych polach tematycznych jest ilość i rodzaj źródeł poświadczających ich występowanie. Nie udało się znaleźć poświadczeń w źródłach po '89 roku dla 14 następujących jednostek leksykalnych:

- 1 cytatu single-up;

- 6 zestawień terminologicznych dwuwyrazowych, np. rzędne kadtuba;

- 5 zestawień terminologicznych trójwyrazowych, np. zakładany obszar uszkodzeń;

- 3 zestawień terminologicznych czterowyrazowych, np. rejon otwarty i głęboki;

- 1 zestawienia terminologicznego pięciowyrazowego: półpodwieszalny ster $z$ jednym czopem. 
Najwięcej, czyli 6 haseł poświadczonych jednokrotnie pochodzi ze Słownika Okrętowego, 3 z Matego Słownika Morskiego, 3 z Vademecum Nawigatora i 1 ze Standardowych Zwrotów Porozumiewania się na Morzu oraz 1 z podręcznika Vademecum Marynarza Pokładowego. Największa ilość jednostek leksykalnych, w tym wypadku 4, mających jedno poświadczenie znajduje się w polu 6. Budowa statku podział przestrzenny, następnie pola 5. Konstrukcja jednostki pływającej i 26. Port, akweny zawierają po 2 takie jednostki, a sześć pól posiada po jednym jednokrotnie poświadczonym haśle. Terminy i profesjonalizmy mające niewielką ilość poświadczeń są rzadko używane w komunikacji dotyczącej zagadnień morskich. Wynika to z ich dużej specjalizacji i są to zazwyczaj pojęcia znane małej grupie nadawców i odbiorców, posiadających wysoce specjalistyczną wiedzę i kompetencje.

Różnice między poszczególnymi polami widoczne są w warstwie wyrazów obcych. Specjalistyczny język ludzi morza, stanowiący narzędzie ich codziennej komunikacji, obfituje w liczne zapożyczenia. Materiał leksykalny zawarty w analizowanych polach tematycznych przejawia różnorodność genetyczną, wynikającą z dużej rozpiętości historycznej okresu, z którego wywodzą się poszczególne nazwy obce, począwszy od starożytności, a kończąc na czasach współczesnych. Za główne kryterium w określaniu źródła pochodzenia jednostki leksykalnej uznano ostatni język stanowiący bezpośrednie źródło zapożyczenia. Największy udział wyrazów obcych posiada pole pierwsze 1 . Historyczne jednostki pływające, w którym na 70 jednostek leksykalnych 56 jest pochodzenia obcego. Zapożyczenia właściwe wywodzą się z 12 źródeł, a ich udział przedstawia się następująco: język francuski 9, włoski 9, grecki 8, holenderski 6, niemiecki 6, łacina 5, angielski 5, hiszpański 3, rosyjski 2, skandynawski 2, perski 2, turecko-osmański 1. Liczba 56 dotyczy zapożyczeń właściwych; w polu tym występuje jeden związek terminologiczny statek okragty <ang. round ship $>$, który stanowi tzw. zapożyczenie ukryte, czyli kalkę frazeologiczną.

Żadna inna grupa tematyczna nie odznacza się podobnym rozwarstwieniem genetycznym, a języki takie jak perski i staroskandynawski nie występują już w innych polach tematycznych. Największa ilość galicyzmów (9) częściowo wynika z faktu, że poprzez francuski dotarł do polszczyzny staroskandynawski leksem drakkar. Jest to też pole o stosunkowo dużym udziale wyrazów obcych pochodzenia greckiego, jak już wspomniano w liczbie 8 , co stanowi $61 \%$ wszystkich greckich zapożyczeń, których całkowita ilość w materiale badawczym wynosi 13. Rozwarstwienie genetyczne analizowanego pola odzwierciedla różnorodne wpływy językowe jakim ulegała polszczyzna, od opisujących rzeczywistość starożytną leksemów greckich, jak np.: panfilia, afrakta, pentera, łacińskich, typu: akacja, birema, triera i perskich, jakdungija, po relikty średniowiecznej kultury skandynawskiej w postaci leksemów snekkar i langskip. Odnajdujemy w tym polu też jednostki leksykalne opisujące realia z XV, XVI i XVII wieku, jak francuskie galeas, galion i karawela, włoskie feluka, galeota, galera i karaka oraz holenderskie fluit, flita, orlog, pinka, szkuta i brander czy hiszpańskie armada, awizo, galeon i niemieckie snigga, sznika. Nieco późniejsze, z przełomu XVIII i XIX wieku, są angielskie żaglowce określane jako kliper, bryg i slup. Zapożyczenia rosyjskie są reprezentowane przez 2 leksemy: starosłowiańskie określenie statku korab oraz rzeczownik skampaweja, z którym łączą się pewne problemy 
natury metodologicznej. Nie udało mi się określić źródła pochodzenia tego leksemu, poza informacją zawartą w jego definicji o budowie tego typu jednostek w Rosji na początku XVIII. W ówczesnym czasie Rosyjska Flota Bałtycka walczyła ze Szwedami na Bałtyku i można jedynie przypuszczać, że w czasach cara Piotra Wielkiego, te szybkie i zwinne galery derywowały swoją nazwę od angielskiego scamper away (zob. The Free Dictionary by Farlex) w znaczeniu 'czmychnąć, szybko uciec'.

Kolejnymi grupami zasługującymi na uwagę jest pole 22.1. Mapy i wydawnictwa nawigacyjne i 28. Dokumenty i prawo morskie ze względu na znaczącą zawartość zapożyczeń strukturalnych, dokładniej kalk frazeologicznych. Rodzime zestawienia terminologiczne odnoszące się do map i publikacji nawigacyjnych używanych przez oficerów na statku wzorowane są na określeniach angielskich, co znalazło odzwierciedlenie w strukturze jednostek leksykalnych, gdzie na 47 jednostek 38 to kalki frazeologiczne, składające się z rzeczownika i uściślającego, uszczegóławiającego przymiotnika, np.: mapa faksymilowa, mapa generalna, mapa gnomiczna, mapa indeksowa, mapa klimatyczna, mapa lodowa, mapa pogody, mapa synoptyczna, mapa nawigacyjna, mapa pilotowa, mapa pomocnicza, mapa rastrowa. Wszelkie publikacje używane na morzu w celu zapewnienia skutecznej i bezpiecznej nawigacji są wydawnictwami w języku angielskim i mają charakter internacjonalny, a angielski stał się podstawowym językiem komunikacji morskiej szeroko stosowanym przez załogi międzynarodowe na morzach i oceanach całego świata. Dużą ilość kalk frazeologicznych odnotowano w polu 28. Dokumenty i prawo morskie, gdzie na 63 jednostki leksykalne 24 to kalki, np.: certyfikat bezpieczeństwa, dziennik okrętowy, dziennik pokładowy, kodeks morski, konferencja żeglugowa, kwit sternika, lista ładunkowa, manifest okrętowy, nota gotowości, protest morski.

Wyróżniającą się cechą pola 25. Działy wiedzy o morzu są leksemy o internacjonalnym charakterze, gdzie na 23 jednostki leksykalne przypada 12 terminów międzynarodowych. Posiadają one tę samą genezę i dostosowały się fonetycznie i formalnie do konkretnych języków, np. w języku polskim dewiacja, angielskim deviation, francuskim déviation, włoskim deviazione. Ich występowanie potwierdza internacjonalne ukierunkowanie szeroko pojętej nauki, nie tylko dyscyplin powiązanych z morzem, gdyż część zawartych w tej grupie nazw to terminy interdyscyplinarne, jak np. automatyka, które nie przynależą tylko do terminologii morskiej, poświadczając $\mathrm{w}$ ten sposób przystawalność i systemowość zasobów terminologicznych, przede wszystkim technicznych. Termin dewiacja jest powiązany nie tylko z naukami technicznymi, w tym morskimi i lotniczymi, czyli aeronautyką, ale też z psychologią. Na granicy kilku dziedzin, takich jak meteorologia i nautyka, funkcjonują pozostałe terminy o podobnym charakterze, określające specjalności występujące w tym polu tematycznym, np.: astronawigacja, hydroakustyka, hydrografia, hydrologia, nawigacja, nautologia, nautyka, oceanografia, oceanologia.

Elementem, który wskazuje na tradycję i historię kontaktów między reprezentantami określonej profesji jest pole 29. Rybołówstwo i sprzęt połowowy. Kontakty językowe z Niemcami, odbywające się poprzez rybołówstwo na Bałtyku i handel, zostały utrwalone w nazwach odnoszących się do podstawowego sprzętu używanego przez rybaków, jaki stanowią sieci. Spośród 9 obcych nazw wspomnianego sprzętu 7 
to germanizmy, np. manca, kacerz, ceza, rafla, net. Również typ wędki takla wywodzi się z języka naszych zachodnich sąsiadów. Z kolei rodzime nazwy sieci odzwierciedlają tradycyjne czynności związane z poławianiem ryb, zachowane w odczasownikowych derywatach typu: cedzak $\leftarrow$ cedzić, plawica $\leftarrow$ plawić, podrywka $\leftarrow$ podrywać (sieć), których podstawy mają też proweniencję regionalną lub gwarową.

Podział na pola jest arbitralny, najlepszym przykładem tej arbitralności jest kategoria 5. Konstrukcja jednostki pływającej. Na całościowy obraz tego pola składają się określenia elementów wchodzących w strukturę statku, począwszy od podstawowych elementów, takich jak stępka i wręgi po części bardziej zaawansowane, na które składa się szereg elementów, jak kadłub. Istotą tego pola jest zawarcie wszystkich elementów konstrukcji w jednej kategorii, bez tworzenia podpól, odnoszących się do fragmentów struktury statku wraz z towarzyszącymi im częściami składowymi. Przykładowe odrębne podpola mogłyby nosić nazwę 5.1 konstrukcja kadłuba, 5.2 konstrukcja pokładu, 5.3 konstrukcja steru etc. Jestem jednak zdania, że zbyt duże rozwarstwienie i rozczłonkowanie poszczególnych pól, a w rezultacie całej makrostruktury opisywanego słownika, mogłoby zakłócić jego jasny i czytelny odbiór przez przyszłych użytkowników.

\section{Podsumowanie i wnioski}

Podsumowując, należy zauważyć, że przedstawiona charakterystyka pól tematycznych stanowi wstęp do dalszych rozważań semantycznych i formalnych na temat współczesnej specjalistycznej leksyki morskiej. Każde z kolejnych 30 pól tematycznych odpowiada określonemu zakresowi rzeczywistości morskiej, a ich charakter jest otwarty, można je zatem wzbogacić o kolejne jednostki leksykalne. Granice omówionych grup nie są stałe, a podział na pola jest moją arbitralną decyzją. W celu ułatwienia pracy ze słownikiem zostanie on uzupełniony o alfabetyczny indeks, dzięki czemu osoby niezaznajomione $\mathrm{z}$ tematyką morską będą mogły z niego swobodnie korzystać. Moim ostatecznym zamiarem w dalszej pracy nad specjalistycznym słownictwem morskim jest publikacja omawianego słownika, zarówno w formie drukowanej, jak i elektronicznej.

\section{Bibliografia}

Babicz, J. (2004), Słownik okrętowy angielsko-polski, polsko-angielski. Shipbuilding dictionary. English-Polish, Polish-English. Gdańsk.

„Bandera” (2011), 1-12.

Buttler, D. (1967), Koncepcje pola znaczeniowego, (w:) „Przegląd Humanistyczny” 2, 41-59.

Cygal-Krupa, Z. (1990), Podstawowe słownictwo tematyczne języka polskiego (na wybranych przykładach). Kraków.

Cygal-Krupa, Z. (2017), Stownictwo tematyczne $w$ teorii i praktyce językoznawstwa polskiego, (w:) R. Przybylska/ W. Śliwiński (red.), Terminologia specjalistyczna w teorii i praktyce językoznawców słowiańskich. Kraków, 97-118.

Dubisz, S. (red.) (2003), Uniwersalny słownik języka polskiego, t. 1-5. Warszawa. 
Doroszewski, W. (red.) (1958-1969), Słownik języka polskiego. Warszawa.

Furmaga, L./ J. Wójcicki (1993), Mały słownik morski. Gdynia.

Gajda, S. (1990), Wprowadzenie do teorii terminu. Opole.

Grabias, S. (1997), Język w zachowaniach społecznych. Lublin.

Grucza, F. (1991), Terminologia - jej przedmiot, status i znaczenie, (w:) F. Grucza (red.), Teoretyczne podstawy terminologii. Wrocław, 11-44.

Grucza, S. (2013), Lingwistyka języków specjalistycznych. Warszawa.

Haber, F. (2009), Podręcznik żeglarza i sternika jachtowego.

Jagniszczak, I/ E. Łusznikow (2010), Bezpieczeństwo Nawigacji. Gdańsk.

Klawe, M. (2014), Analiza terminograficzna angielsko-polskich i polsko-angielskich słowników medycznych wydanych w Polsce w latach 1990-2012, (w:) M. Łukasik/ B. Mikołajewska (red.), Języki specjalistyczne wczoraj, dziś i jutro. Warszawa, 115-126.

Ligara, B. (2017), Terminologia specjalistyczna i kultura: dychotomia czy punkty wspólne?, (w:) R. Przybylska/ W. Śliwiński (red.), Terminologia specjalistyczna teorii i praktyce językoznawców słowiańskich. Kraków, 29-52.

Lukszyn, J. (2005) (red.), Języki specjalistyczne. Słownik terminologii przedmiotowej. Warszawa.

Lukszyn, J./ W. Zmarzer (2006), Teoretyczne podstawy terminologii. Warszawa.

Łączyński, B./ A. Starosta (2006), Plan ładunkowy statku handlowego. Gdynia.

Łączyński, B. (2007), Przewozy Morskie. Część pierwsza. Gdynia.

Łukasik, M. (2007), Angielsko-polskie i polsko-angielskie słowniki terminologiczne (1990-2005). Analiza kwantytatywna, (w:) M. Kornacka (red.), Języki specjalistyczne 7. Teksty specjalistyczne jako nośniki wiedzy fachowej. Warszawa, 163-176.

Markowski, A. (1992), Leksyka wspólna różnym odmianom polszczyzny, t. I-II. Wrocław.

Markowski, A. (2012), Wykłady z leksykologii. Warszawa.

Miodunka, W. (1980), Teoria pól językowych, społeczne i indywidualne ich uwarunkowania. Warszawa/ Kraków.

„Namiary na morze i handel” (2008), 1-24.

„Nasze Morze” (2008), 1-12.

Nowicki, A./ Kabaciński J. (2008), Podstawy manewrowania statkiem morskim. Kurs manewrowania na symulatorze. Szczecin.

Plucińska, E./ J. Kłosiński (2011), Standardowe zwroty porozumiewania się na morzu. Szczecin.

Puchalski, J. (2007) Ilustrowany angielsko-polski słownik marynarza. Gdynia.

Pytel, W.A. (2003), Identyfikatory semantyczne tekstów specjalistycznych, (w:) J. Lukszyn (red.), Języki Specjalistyczne 3. Warszawa, 59-73.

Rymarz, W. (1998), Podręcznik Międzynarodowego Prawa Drogi Morskiej. Gdynia.

Tokarski, R. (1984a), Granice pola znaczeniowego, (w:) K. Polański (red.), Słownictwo w opisie języka. Katowice.

Tokarski, R. (1984b), Struktura pola znaczeniowego (studium językoznawcze). Warszawa.

Wierzchowski, J. (1980), Semantyka językoznawcza. Warszawa. 
Wróbel, F. (2009), Vademecum Nawigatora. Gdynia.

„Żagle” (2008), 1-12.

\section{Źródla internetowe}

Gospodarka Morska. (URL http://www.gospodarkamorska.pl/). [Pobrano 5.04.2018]. Nasz Battyk. (URL http://www.naszbaltyk.com/). [Pobrano 5.04.2018]. Polski Rejestr Statków. (URL https://www.prs.pl/). [Pobrano 5.04.2018].

Portal Morski. (URL www.portalmorski.pl/). [Pobrano 5.04.2018].

The Free Dictionary by Farlex. (URL https://idioms.thefreedictionary.com/scamper+away). [Pobrano 4.02.2018]. 